\title{
Problematizações sobre o exercício de ver: mídia e pesquisa em educação *
}

\author{
Rosa Maria Bueno Fischer \\ Universidade Federal do Rio Grande do Sul, Faculdade de Educação
}

O que a filosofia da visão ensina à filosofia? Que ver não é pensar e pensar não é ver, mas que sem a visão não podemos pensar, que o pensamento nasce da sublimação do sensível no corpo glorioso da palavra que configura campos de sentido a que damos o nome de idéias. Que o pensamento não são enunciados, juízos, proposições, mas afastamentos determinados no interior do Ser. Que não é contato invisível de si, interioridade transparente e presença a si, mas excentricidade perante nós a partir de nós, "estrelas de Van Gogh" e espinhos em nossa carne. Que o conceito não é representação completamente determinada, mas "generalidade de horizonte" e a idéia não é essência, significação completa sem data e sem lugar, mas "eixo de equivalências", constelação pro-

* Algumas das discussões deste texto fazem parte do trabalho "O dentro e o fora da recepção: por uma análise da heterogeneidade dos processos comunicacionais", apresentado no XI COMPÓS - Encontro Nacional dos Programas de Pós-Graduação em Comunicação, realizado na UFRJ, de 4 a 7 de junho de 2002, no GT “Mídia e Recepção".

\author{
visória e aberta do sentido. Ensina que, assim como o \\ visível é atapetado pelo forro do invisível, também o pen- \\ sado é habitado pelo impensado.
}

Chaui, 1999, p. 60-61

\section{Introdução}

O belíssimo texto de Marilena Chaui, "Janela da alma, espelho do mundo", serve de mote para este artigo, tendo em vista que sintetiza, poética e filosoficamente, algumas das várias problematizações que pretendo fazer aqui, a respeito das pesquisas em educação que têm como objeto ou como material empírico as imagens da televisão ou as diferentes formas de veicular e receber produtos da mídia televisiva. Pergunto-me: como estudar as imagens, textos e sons da mídia, especialmente da televisão, tendo como pressuposto que não extrairemos das imagens representações acabadas, mas antes possibilidades de significação, datadas e bem localizadas, seja do ponto 
de vista daqueles que as produziram e colocaram em circulação, seja do ponto de vista daqueles que a receberam e, com ela, de alguma forma, interagiram? Como o analista das imagens da mídia tratará o fato de ele mesmo ser alguém que especta, que olha, que investe seu corpo nesse jogo de interioridade e de exterioridade que diz respeito ao ato de ver, de receber imagens e de operar sobre elas - como espectador comum do cotidiano e, simultaneamente, como estudioso das questões da comunicação no âmbito da pesquisa educacional? Finalmente, de que modo, ao investirmos nos estudos sobre televisão, efetivamente participamos de uma elaboração da história do presente, já que as imagens que nos ocupam são de alguma forma "espinhos em nossa carne"?

Apoiada em autores como Paul Veyne, Michel Foucault e Gilles Deleuze (sobretudo no que diz respeito à historicidade do ver e do falar), e em estudiosos como Beatriz Sarlo, Jesús Martín-Barbero (no que se trata da especificidade da cultura visual midiática), discuto aqui elementos de uma proposta metodológica para investigações que, no campo educacional, tenham como centro de atenção os produtos da mídia, particularmente da televisão. Nessa proposta, sugiro que se faça uma análise do discurso (no caso, da mídia), atentando para as práticas discursivas e não-discursivas em jogo no complexo processo de comunicação que se opera entre criadores, produtores, atores, técnicos de todos os níveis, e os espectadores, nas mais distintas situações e condições de recepção.

Mais do que isso, proponho que nessa análise do discurso se busquem os enunciados de certos discursos, de certos regimes de verdade, próprios de uma época, produzidos, veiculados e recebidos de formas muito específicas, que falam de um certo tempo e lugar, que falam de determinadas relações de poder, que produzem sujeitos de uma certa forma. Interesso-me especialmente pelos enunciados daquelas discursividades que tenham presença ou repercussão significativa no campo da educação: refiro-me a determinados modos de existência propostos na mídia a crianças, a jovens, a educadores, modos que não se separam de modos de enunciação, de práticas de linguagem, de celebração de certas verdades tornadas hegemônicas.

\section{O visível e o enunciável}

Como escreveu Foucault (1986), em A arqueologia do saber, os discursos não confrontam nem associam realidade e língua, léxico e experiência; nem devem ser vistos como conjuntos de signos que aí estão para remeter a este ou àquele conteúdo, a esta ou àquela representação. Os discursos são sempre práticas que efetivamente "formam os objetos de que falam" (p. 56), e não se reduzem a um conjunto de "falas", de imagens ou de textos que selecionamos para analisar. Poderíamos dizer que os enunciados de um discurso seriam uma espécie de lugar de chegada de um trabalho minucioso do pesquisador, uma vez que este buscará descrever os diversos modos pelos quais é tecido, discursivamente, o social. Estamos falando aqui do social como constituído e ao mesmo tempo como constitutivo da linguagem, e do discurso como imerso por definição em relações de poder. Como escrevi em outro texto (Fischer, 2001a), descrever enunciados de um discurso é apreender esse mesmo discurso como acontecimento, como pertencente a uma certa formação discursiva (o discurso pedagógico do século XIX, por exemplo; o discurso feminista dos anos de 1960; o discurso da medicina, nos seus diferentes momentos; e assim por diante), como ligado a um certo regime de verdade e, ainda, como diretamente relacionado à constituição de sujeitos individuais e sociais.

Ora, quando proponho que se faça uma análise do discurso da mídia que dê conta do discursivo e do não-discursivo, estou me referindo a uma opção investigativa que se ocupe do visível e do enunciável de determinados discursos veiculados na mídia contemporânea. Ou seja, considerando os diferentes níveis de uma análise de produtos televisivos, imagino que seja possível - aliás, como alguns pesquisadores já têm feito ${ }^{1}$ - descrever certos discursos de nosso tempo, numa operação que faça emergir a com-

${ }^{1}$ Só a título de exemplo, lembro aqui dois estudos aos quais tive diretamente acesso: o de Luís Henrique Sacchi dos Santos (2002) e o de Paola Menna Barreto Gomes (2000). No primeiro, a 
plexidade do que tenho chamado de "dispositivo pedagógico da mídia"² (Fischer, 2000, 2001b, 2001c), com suas técnicas e estratégias específicas de interpelação dos sujeitos. Mas o que seria exatamente o "visível" e o que seria o "enunciável", em se tratando de programas de tevê, eleitos por nós como "documentos"?

Parece-me que o visível (jamais separado do enunciável), aqui, poderia ser pensado como uma trama de visibilidades, a saber: a) o próprio produto, um programa ou um conjunto " $x$ " de programas de televisão, com toda a riqueza de sua linguagem audiovisual, que poderá ser analisada nos detalhes específicos dessa linguagem: o roteiro, os diversos "blocos" do programa, os atores ou personagens em jogo, a sonorização, o texto propriamente dito, a cenografia, o gênero de programa (ficção, jornalismo, publicidade, humor, musical, reality show, talk show, e assim por diante), a edição, a seleção de planos, a sintaxe das seqüências narrativas; b) o produto e sua inserção numa política global de produção e veiculação, numa determinada emissora ou num conjunto de emissoras de tevê aberta ou a cabo, com as diferentes estraté-

temática da prevenção da AIDS e do HIV no Brasil é discutida a partir da análise de filmetes produzidos pelo Ministério da Saúde e veiculados na televisão; no segundo, os modos de constituir a mulher, seu corpo, seus afetos, sua sexualidade, é investigado a partir das narrativas destinadas ao público infantil, como os filmes de animação de Walt Disney. Em ambos, faz-se uma análise detalhada de linguagens específicas (o cinema na indústria do entretenimento e os filmetes de propaganda oficial para veiculação em tevê), ao mesmo tempo em que se discutem problemas fundamentais da sociedade contemporânea, como os relativos aos modos de existência propostos nesses materiais quanto às questões de gênero e às formas de sexualidade constituídas como verdades a serem aprendidas e vivenciadas.

${ }^{2}$ Defino "dispositivo pedagógico da mídia” no texto “ "Técnicas de si' na TV: a mídia se faz pedagógica", como um aparato discursivo e ao mesmo tempo não-discursivo a partir do qual haveria formas muito particulares de produção do sujeito contemporâneo (Fischer, 2000, p. 115). gias de captura de determinados públicos, em certas épocas e horários; c) os modos de articulação do público com o produto veiculado, dados por situações muito diferentes, como as pesquisas de marketing e as pesquisas de audiência, as manifestações dos receptores buscadas e veiculadas pela própria televisão ou por outros meios de comunicação, como jornais e revistas; também as formas de participação e intervenção do público, permitidas por outras situações, como aquelas que se dão no âmbito das próprias pesquisas de recepção; d) finalmente, a trama de visibilidades teria a ver igualmente com as condições de produção e de emergência de certos discursos que circulam em determinados produtos da mídia, em certa época e lugar; trata-se aqui das práticas institucionais, dos acontecimentos políticos, dos diferentes processos econômicos e culturais que, como nos ensina Foucault, não seriam "expressão" de um discurso nem sua causa imediata, mas algo "que faz parte de suas condições de emergência" (Foucault, 1986, p. 187). Fica claro, portanto, que falar de visibilidades é falar também de enunciados, daquilo que se "murmura", das coisas ditas em determinado tempo e lugar.

Para exemplificar, trago imagens que hoje são presença obrigatória na televisão, nas revistas, nos jornais: a figura das meninas adolescentes que ascendem meteoricamente ao estrelato do chamado mundo fashion. Se nos debruçarmos sobre essas imagens, sobre a reiteração desses corpos jovens, quase infantis, sobre a insistência de seus olhares duros e frios, distantes, atemorizadores até, podemos descrever um pouco dessa discursividade de elogio a um corpo que se faz belo e desejável de um determinado modo, e que se associa àquilo que Jurandir Freire Costa chama de cultura das sensações, de cultivo de uma "subjetividade exterior" (Costa, 2001). Tudo indica que tal discurso se constrói a partir de outros discursos, ou a eles se associa, sem medo de uma possível incongruência. Aliás, parece fazer-se exatamente dessa fragmentada incongruência: nos textos e imagens que oferece sobre a última novidade no mercado das passarelas, a mídia é capaz de nos remeter àquele fato como "coisa do mercado", como sucesso econômico 
e profissional, simultaneamente como revelação de uma inocência bela a se expor a nossos olhos e, ainda, como oferta de "carne", de "suculência". ${ }^{3}$ Em outras palavras: o discurso hedonista de nosso tempo associa-se, sem qualquer pudor, a um discurso politicamente incorreto, relacionado a uma sugestão pouco velada de pedofilia - mesmo que a mesma mídia, a mesma emissora ou rede, por vezes até simultaneamente àquele tipo de emissão, dediquem-se "sinceramente" a combater o crime de assédio sexual de adultos a crianças e adolescentes.

Assim, tratar de visibilidades, na análise enunciativa proposta por Foucault, significa tratar dos espaços de enunciação de certos discursos - espaços institucionais muito definidos, como é o caso da escola, por exemplo, e espaços mais fluidos e amplos, como é o caso da mídia, em sua relação com os vários poderes, saberes, instituições que nela falam. Nesse sentido, poderia dizer-se que a mídia se constitui um espaço de "visibilidade de visibilidades"; ela e suas práticas de produção e circulação de produtos culturais constituiriam uma espécie de reduplicação das visibilidades de nosso tempo. Da mesma forma, poderíamos dizer que a mídia se faz um espaço de reduplicação dos discursos, dos enunciados de uma

${ }^{3}$ Eventos da moda como os conhecidos "São Paulo Fashion" e "Rio Fashion", que trazem modelos famosas como Gisele Bündchen ou Naomi Campbell, ao lado de novas meninas brasileiras, são descritos na mídia com a voluptuosidade de palavras que seguidamente remetem à associação da mulher e do corpo feminino com tudo o que diga respeito a apetite, fome, prazer visual-oral. Exemplo disso foram duas reportagens, uma na revista semanal ISTOÉ, edição no 1713, de 31 de julho de 2002 (em que se fala num desfile que conseguiu "números robustos", "resultados suculentos", numa matéria que dá espaço especial à atriz Luana Piovani, que desfilou de seios sustentados apenas pelas mãos da modelo), e outra no Caderno Donna do jornal Zero Hora do dia 27 de julho de 2002 (em que uma nova modelo, de 15 anos, gaúcha do município de Viamão, na Grande Porto Alegre, é saudada como nova promessa e elogiada pelo sucesso que fez, em virtude de ter coberto "inocentemente" os seios que se expuseram nus, por um problema com o aplique de cabelos da menina). época. Mais do que inventar ou produzir um discurso, a mídia reduplicá-lo-ia, porém, sempre a seu modo, na sua linguagem, na sua forma de tratar aquilo que "deve" ser visto ou ouvido. Isso quer dizer, então, que ela também estaria simultaneamente replicando algo e produzindo seu próprio discurso, sobre a mulher, sobre a criança, sobre o trabalhador ou, no caso do exemplo anterior, sobre a juventude ou a adolescência das passarelas.

A propósito da discussão sobre o fato de a televisão ou a mídia produzirem ou apenas replicarem discursos, é bem instigante a observação que fazem Deleuze e Guattari (2001), em O que é a filosofia?. Os filósofos lembram como em nosso tempo uma das reivindicações do campo da comunicação (e de seus correlatos, como a informática, o design, a publicidade; eu acrescentaria: da moda e da mídia, de uma maneira mais ampla) é justamente a de que é nesses espaços que ocorre a criação, ali é que se inventam até mesmo "conceitos" (o estilista dirá, por exemplo, que seu último desfile foi totalmente "conceitual"). Trata-se de um bom exemplo de como os meios de comunicação e todas as suas "disciplinas" produzem (ou se apropriam de) certos discursos. Trata-se de uma luta, de disputas de poder muito específicas, a partir das quais (ou no interior das quais) se fazem e refazem os discursos, os saberes especializados, bem como os modos de nos tornarmos sujeitos de certas verdades. Reivindicar para si o grande e exclusivo lugar da criação, no caso da mídia e da publicidade, seria um modo de ensinar a todos nós que outros espaços (como o da filosofia, da literatura, da própria educação, da arte) teriam deixado de ser importantes em nosso tempo.

Portanto, analisar discursos significa em primeiro lugar não ficar no nível apenas das palavras, ou apenas das coisas; muito menos, buscar a bruta e fácil equivalência de palavras e coisas. Como escreve Deleuze (1991), o visível tem suas próprias leis, desfruta uma certa autonomia em relação ao enunciável, justamente porque "as coisas ditas" também têm sua relativa autonomia. Em suma, o visível e o enunciável não se reduzem um ao outro, eles exercem uma 
espécie de força um sobre o outro, de tal forma que haveria simultânea e permanentemente "a lição das coisas $e$ a lição da gramática" (p. 60, grifo do autor). E é essa heterogeneidade dos ditos e das visibilidades que proponho seja descrita em nossas investigações sobre produtos midiáticos. Quando afirmo que a mídia se constituiria um espaço de "visibilidade de visibilidades", não estou aqui confundindo visibilidade com elementos visuais, com objetos palpáveis, mostrados em suas qualidades sensíveis stricto sensu. Sim, vamos operar sobre programas de tevê que gravamos, materiais que manipulamos e que buscamos descrever em suas minúcias de materialidade audiovisual. Mas a visibilidade que vamos descrever diz respeito a um trabalho minucioso e árduo de abrir, "rachar" essas imagens, textos e sons, abrir e rachar a minúcia das práticas institucionais relativas ao ver e ao fazer ver da televisão num país como o Brasil, abrir e rachar as coisas ditas nos telejornais e telenovelas, nos comerciais e nos reality shows, e extrair deles alguns (mesmo que poucos) enunciados (idem, p. 62) - sabendo que não há verdades ocultas nem visibilidades tão plenamente expostas nem tão evidentes.

"Que tudo seja sempre dito, em cada época, talvez seja esse o maior princípio histórico de Foucault: atrás da cortina não há nada para se ver, mas seria ainda mais importante, a cada vez, descrever a cortina ou o pedestal, pois nada há atrás ou embaixo" (Deleuze, 1991, p. 63). Por mais que protestemos, é preciso enfrentar o fato de que não há enunciados escondidos naquilo que a mídia produz e veicula; o que há são emissores e destinatários dos meios de comunicação (como o rádio, a tevê, as revistas e jornais), que variam conforme os regimes de verdade de uma época, e de acordo com as condições de emergência e de produção de certos discursos. Portanto, há que olhar para essa complexidade dos processos comunicacionais, procurando não o que estaria escamoteado, mas os modos de se fazer verem certas coisas num determinado tempo. Pode ser paradoxal, mas o que nos ensina Foucault é que, se ficarmos nas evidências, na ilusão das coisas em si, palpáveis e plenamente visíveis, aí é que não as veremos naquilo que importa, naquilo que Deleuze chama de "condição que as abre" (idem, p. 66).

O interesse de Foucault pelos espaços institucionais, como a prisão, o hospital, ${ }^{4}$ remete ao fato de que olhar para esses lugares tão concretos e tão palpáveis, nessa perspectiva, significa tratar de dimensões de exterioridade de funções como a de isolar, seqüestrar corpos, classificar - funções diretamente relacionadas a enunciados de um discurso específico, o discurso da sociedade das disciplinas. Foucault chegou a enunciar essas funções não porque para ele haveria uma perfeita correlação entre um visível e um enunciável, mas porque a minuciosa e complexa investigação de um sem-número de modos, procedimentos, enfim, práticas discursivas e não-discursivas, de produzir isolamentos, totalizações e distinções entre os indivíduos, lhe permitiu "ver" isso, construir essa história das prisões, mostrar como nos constituímos desse jeito no Ocidente, numa certa época.

Como escreve Paul Veyne no conhecido texto "Foucault revoluciona a História", a filosofia de Foucault não é uma filosofia do discurso, mas uma filosofia da relação (Veyne, 1982, p. 177). E é disso que estamos tratando aqui, quando propomos um modo de tomar a mídia, seus ditos e a suas visibilidades como objeto de nossas investigações no campo educacional. Na esteira dessa filosofia, recusamos a idéia de que se deva, por exemplo, estudar a televisão e seus produtos para expor única e exclusivamente a maquinaria de uma forma de manipulação de crianças, adolescentes, homens e mulheres das camadas populares. No lugar disso, propomos uma investigação que se aventure a responder a uma série de relações, de "comos", que se aventure a perguntar sobre as sucessivas transformações no grande tabuleiro social, em que arranjos de poder e de saber são continuamente feitos, e que podem ser "apanhadas" justa-

${ }^{4}$ A descrição da história das prisões, feita pelo autor, em Vigiar e punir (Foucault, 1991), merece ser consultada, se desejarmos apreender melhor essa inseparabilidade entre o visível e o enunciável. 
mente nesse lugar específico de enunciação, que é a mídia. Assim, nessa perspectiva, interessaria muito um estudo que pudesse responder de que modo, nesse lugar das imagens em zapping, da informação fragmentada, da narrativa das celebridades e dos acontecimentos-bomba, nesse paraíso dos corpos, se produzem certas formas de sujeição em nosso tempo, relativas a como investimos tempo e energia na transformação de nossos corpos infantis, adultos, adolescentes, nossos corpos masculinos e femininos; ou então um estudo que não temesse imiscuir-se nas inúmeras práticas aprendidas diariamente através do que vemos na televisão, sobre nossos modos de olhar o outro, de constituir os diferentes de nós, os pobres, os adolescentes, ${ }^{5}$ as mulheres, as mães,${ }^{6}$ as professoras, os que encarnariam a imagem do mal, ${ }^{7}$ do indesejável, daquilo que merece ser eliminado ou "detonado", 8 e assim por diante.

\section{Modos midiáticos de ser}

As análises da estudiosa argentina Beatriz Sarlo talvez sejam aqui as mais adequadas para exemplificarmos de que modo é possível fazer da mídia objeto de estudo, para dessa maneira falar sobre nosso tempo, problematizar nosso cotidiano, fazer a história de nosso presente, sem procurar os não-ditos, as verdades recalcadas, mas antes descrever como nos vamos constituindo deste e não daquele jeito, no caso, a partir da ação da mídia ou, pelo menos, com sua insistente participação. No instigante texto "A democra-

${ }^{5}$ Veja-se a propósito a dissertação de mestrado de Celso Vitelli (2002).

${ }^{6}$ Aqui lembro a pesquisa de Fabiana de Amorim Marcello (2002), que investiga de que modo se constrói na mídia um discurso sobre a maternidade hoje.

${ }^{7}$ A propósito desse tema, das figurações do mal na cultura contemporânea, remeto à pesquisa de Paola Menna Barreto Gomes (2002).

${ }^{8}$ Expressão usada no programa Big Brother Brasil pelo apresentador Pedro Bial, nas ocasiões de votação do participante que deveria ser eliminado do reality show. cia midiática e seus limites" (Sarlo, 1997b), a autora analisa, por exemplo, de que modo a televisão argentina participou de uma verdadeira guerra, cujos participantes eram um casal e sua filha pequena, além da própria televisão, seus jornalistas, suas equipes de produção e o público telespectador. A separação dos pais argentinos, que se casaram no Canadá, e a luta pela posse da criança que fora com a mãe para Buenos Aires passaram a ser objeto de intensa atenção da tevê. Para Sarlo, o fato interessa não pela óbvia espetacularização da vida privada e do sensacionalismo daí decorrente, mas especialmente porque mobiliza uma série de discursos produzidos a partir da mídia televisiva: por exemplo, o discurso do orgulho nacional e o discurso de uma suposta ordem natural a ser defendida, justamente aqui e agora, num mundo de sentidos morais erodidos (ambos a justificarem a permanência da menina na Argentina, com a mãe).

Da mesma forma, a autora - como acontece em outros textos seus sobre cultura e mídia ${ }^{9}$ - mostra de que modo vida cotidiana, cidadãos comuns e tevê se irmanam: a mãe em questão, segundo Sarlo, emerge como uma personagem midiática, perfeitamente adequada ao meio, alguém que encontrou a oportunidade para devolver à própria tevê o que com ela aprendeu (a mãe praticamente faz o papel de diretora e roteirista dos programas relativos a seu drama). Mais do que isso: na análise de Sarlo, aparece a televisão como organizadora e catalisadora de um debate nacional, sobre o qual todos se pronunciam. Mesmo numa época de graves problemas econômicos, o povo argentino vê-se às voltas com uma mínima história privada, e isso toma conta das audiências, como se não fosse possível viver de outra forma, como se não saber da história do casal fosse estar privado de estar com todos num espaço público. Em nosso país, não é diferente, e somos todos reféns do Big Brother Brasil. Como escreve Sarlo,

${ }^{9}$ Refiro-me aqui aos ensaios do livro Cenas da vida pósmoderna: intelectuais, arte e videocultura na Argentina (Sarlo, 1997a). 
A esfera midiática introduziu inúmeras modificações na apresentação dos problemas que magnetizam a sociedade, mas o que fez com maior originalidade foi o rearranjo de fronteiras entre o que é público e o que é privado. Como conseqüência disso, alterou-se a relação entre os fatos que afetam a todos os cidadãos e aqueles cuja projeção diz respeito apenas aos que estão privada e diretamente envolvidos em um conflito. Emerge uma solidariedade do privado em uma sociedade que está perdendo critérios públicos de solidariedade. (1997b, p. 123-124)

O exemplo acima é paradigmático da metodologia de investigação que faço neste artigo: proponho que as imagens audiovisuais sejam tomadas na sua materialidade específica, na sua condição de tal ou qual gênero de programa televisivo, mas que exatamente essa operação sobre os textos, figuras, sonoridades, cores e movimentos da tevê se faça concomitantemente a um trabalho de auscultação dos sujeitos envolvidos, das personagens que se deixam ver ou que são convidadas ou expostas a um certo tipo de visibilidade, também dos produtores, criadores, jornalistas, especialistas, todos os participantes de uma trama narrativa em que se fazem circular alguns discursos. Que discursos são esses? Que enunciados podem ser extraídos dessas enunciações televisivas? Que campos de saber se aliam ou se contrapõem entre si nesse lugar específico? Que modos de subjetivação podem ser aî identificados? Na análise de Sarlo (1997b), o acontecimento midiático é fonte de uma discussão sobre democracia, sobre as redefinições do público e do privado, sobre o que seria a participação popular, a pesquisa de opinião (vendida na mídia como prática democrática), e permite que a autora conclua, sobre o episódio:

[...] as paixões sitiam as instituições cuja eficácia não parece evidente, enquanto o imaginário tece sua crença de que há verdades mais simples, mais imediatas e mais naturais. Todo o problema da cultura contemporânea resume-se neste conflito em que o vazio de compromissos significativos comuns é compensado por um emaranhado de laços simbólicos que operam provavelmente com mais força sobre quem está mais excluído das grandes decisões que definem sua vida. (p. 128)
O que essa autora nos sugere é que os modos pelos quais a mídia existe em nosso tempo são instauradores de uma nova ordem, a ordem da videopolítica, ${ }^{10}$ segundo a qual as tecnologias de comunicação produzem modos de existência, estilos, que se apresentam como "naturais", como imediatos, sugerindo que a familiaridade das imagens televisivas e das páginas de jornais e revistas se imponha como garantia de verdade, de "afetuosa" partilha de cotidianos, e não de jogo de interpelação. Todos, pela ação da mídia, políticos especialmente, precisam fazer-se populares, íntimos, "imediatos", atores da indústria do entretenimento, com um certo estilo discursivo que elimina as "complicações" semânticas e sintáticas, os torneios de linguagem, as metáforas mais elaboradas, a sofisticação das diferenças de linguagem e de estilos, bem como a particularidade, a singularidade de cada evento, de cada indivíduo ou de cada grupo tornado visível aos olhos do mundo pela tevê. Há na mídia uma equivalência de temas, valores, afetos, saberes: é assim que, por exemplo, a atriz de telenovela poderá estar lado a lado com um ministro de Estado ou com um catedrático de renomada instituição universitária, e opinará sobre a violência praticada com crianças pequenas no Brasil.

Esse "ar democrático" da mídia, segundo Beatriz Sarlo, precisa ser investigado no que concerne às novas relações que têm se estabelecido entre sistema político, cidadania e opinião pública (1997b, p. 138). No âmbito deste artigo, tais observações reforçam a proposta de que a análise do discurso da mídia, nas pesquisas educacionais, precisa dar conta exatamente dessa complexa trama - de uma linguagem específica, a audiovisual, em correlação com os sentidos que nela circulam e são construídos, elementos que não se separam de modos de ser e estar, ensinados exatamente no interior dessas práticas de produção, veiculação, recepção de produtos midiáticos. Visualidade eletrônica é hoje parte cons-

10 Ver, a propósito, o artigo "Sete hipóteses sobre a videopolítica" (Sarlo, 1997b, p. 129-138). 
titutiva da visibilidade cultural (Martín-Barbero e Rey, 2001), e é isso que precisamos investigar. O estilo discursivo da televisão, como referi anteriormente, produz alterações até mesmo nos modos de concebermos como deve ser um político, um professor, um religioso: as instituições cada vez mais são julgadas, vistas, concebidas em relação com um tipo de performance audiovisual (não é à toa que emergem figuras como o padre Marcelo, o professor Pasquale, ou políticos performáticos como o eterno candidato Enéas). Analisar, portanto, o discurso da mídia, no âmbito das pesquisas educacionais, será mergulhar num tipo específico de linguagem, a audiovisual, ${ }^{11}$ tendo selecionado um conjunto expressivo de materiais, exatamente porque podem dar conta dessas paisagens imaginárias de nosso tempo, e têm uma presença efetiva no cotidiano dos sujeitos sociais, dos alunos, meninos e meninas, crianças, adolescentes, dos professores e professoras, com os quais interagimos no cotidiano escolar.

Imagino, portanto, que a leitura dos materiais audiovisuais e o estudo das estratégias de produção, criação e veiculação dos produtos da mídia não percam de vista a dimensão das profundas repercussões dessas práticas na vida das pessoas. Ou seja, emerge, hoje, mais do que nunca, a necessidade de complexificarmos nossas investigações a respeito do receptor que, na falta de um nome melhor, ainda assim é chamado. A quem se endereçam os produtos televisivos? Como pergunta Elizabeth Ellsworth (1997), quem se

${ }^{11}$ Arlindo Machado (1998) oferece elementos bastante ricos para nos apropriarmos da tecnologia de produção, veiculação e recepção das imagens audiovisuais eletrônicas. Modestamente, em meu livro Televisão \& educação: fruir e pensar a TV, especialmente no capítulo "As imagens e nosso olhar atento: com que linguagens opera a TV?", também sugiro formas de abordar as imagens televisivas (Fischer, 2001c). Sugiro também a leitura do livro de Gillian Rose (2001), que, aliás, serviu de referência para as análises feitas por Luis Henrique Sacchi dos Santos (2002), já referidas acima, sobre anúncios televisivos de campanhas oficiais de prevenção à AIDS e ao HIV. pensa que é aquele a quem se destina tal ou qual programa? Quem aquela emissora ou aquele criador imagina que eu sou, que nós somos, que esta criança é? E quem se deseja que sejamos? Podemos apreender esses "modos de endereçamento" na própria análise dos programas, porque o espectador está de alguma forma lá, foi projetado, imaginado pela tevê, e nessa medida ele existe. Mas proponho que se vá adiante, que se busquem formas de investigação pelas quais seja possível estabelecer um movimento permanente entre a análise dos produtos midiáticos e a escuta de grupos selecionados de espectadores - cujas falas, assim como os textos midiáticos escolhidos, constituiriam, ambos, o corpus de nossa análise.

De qualquer modo, penso que o fundamental seja montar uma estratégia básica de abordagem dos materiais midiáticos, a saber: a elaboração de ferramentas de pesquisa que tenham uma espécie de coerência interna, de tal forma que a própria temática em questão esteja articulada com a criação de categorias de análise, a escolha dos conceitos teóricos, a operacionalização desses mesmos conceitos e, evidentemente, a análise e interpretação dos dados. Como vimos no exemplo de análise feita por Beatriz Sarlo, o tratamento das várias reportagens e matérias sobre o casal argentino e seu conflito conjugal contemplou simultaneamente uma análise minuciosa da linguagem stricto sensu da tevê, das interpelações em direção aos espectadores; jamais, porém, a autora desvinculou essa análise de um trabalho detalhado sobre a temática da democracia, de videopolítica, e especialmente da temática dos novos arranjos das esferas pública e privada.

\section{Pesquisar, ou: problematizar o presente}

Em suma, esta proposta, feita com base em uma série de pesquisas - incluindo-se aqui não só a pesquisa acadêmica, ${ }^{12}$ mas estudos qualitativos de audiência e até mesmo criação de programas para crianças,

${ }^{12}$ Ver, a propósito, Fischer, 1993; 1996a; 1996b; 2000; 2001b). 
adolescentes e professores ${ }^{13}-$, considera a hipótese de que a riqueza das análises dos produtos dos meios de comunicação, como fatos culturais e sociais (seja aquela feita exclusivamente sobre a linguagem ou as representações e discursos presentes em produtos midiáticos, seja aquela que se dedica à escuta de sujeitos participantes de "grupos de recepção") estaria na criação de ferramentas de análise complexas, segundo uma perspectiva que vem sendo defendida por Edgar Morin (1999) e tantos outros pensadores: deixar de pensar e de conhecer a partir da separação (entre ciência e filosofia, entre real e imaginário, entre cultura científica e vida, entre técnica e homem, entre o que vemos e aquilo ou aquele que nos olha ${ }^{14}$ ), mas procurar construir novas formas de investigação da realidade que operem a partir de uma série de diferenciações, "tecendo" o conhecimento a partir da complexidade do real. Mesmo que venhamos a construir unidades, defendo que estas sejam provisórias e que dêem conta do que Hannah Arendt (2000) chama de pluralidade, agonismo, teatralidade e performatividade - referindo-se ao agir humano no espaço público. Sem desmerecer outros estudos mais tópicos (análise de um filme ou da performance de um apresentador de $\mathrm{TV}$, estudos de recepção com grupos de crianças de uma escola " $x$ " etc.) - cuja contribuição tem sido inestimável para a compreensão de como estamos produzindo sentidos na cultura, a partir das diferentes práticas (políticas, estéticas, econômicas, de lazer e entretenimento etc.) relacionadas à produção e ao consumo de materiais da mídia -, o que proponho aqui é o exame e o debate de uma possibilidade de investigação que efetivamente problematize nossos modos de ver hoje (no sentido foucaultiano de pro-

${ }^{13}$ Refiro-me aqui à experiência na TV Educativa do Rio de Janeiro, como pesquisadora e como coordenadora de produção de programas educacionais (de 1979 a 1990).

${ }^{14}$ Sobre essa relação entre o que vemos e como somos vistos, sugiro, além da obra de Didi-Huberman (1998), a leitura de John Berger (1999), livro de ensaios abordando as implicações da expansão dos meios de comunicação sobre nossos modos de ver contemporâneos. blematização, ver Foucault, 1995), articulando um mergulho nas imagens da mídia, nos discursos que ela faz circular e nos modos de subjetivação que eles incitam.

Certamente não suponho, com essa proposta, estar inaugurando um modo novo de estudar os processos comunicacionais midiáticos. Antes, o que faço é pôr em funcionamento uma série de "achados" metodológicos, que vários outros estudiosos vêm alcançando, divulgando e, principalmente, colocando em prática em suas investigações, nas duas últimas décadas. Em termos gerais, diria que me alinho com o que Jesús Martín-Barbero (1995) defende, ao fazer uma revisão histórica sobre os estudos de recepção em comunicação social: para esse autor, estudar a recepção implica, necessariamente, apanhar o processo inteiro e complexo da comunicação. Mais do que isso: há que se atentar não só para a heterogeneidade das temporalidades, como para os novos sujeitos sociais, ou, como diz o autor, as novas fragmentações sociais e culturais (Martín-Barbero, 1995, p. 44). ${ }^{15}$ Seguindo Raymond Williams, vários pesquisadores da comunicação - como é o caso de Sílvia Borelli (1995), Nilda Jacks (2000), Mauro Wilton de Sousa (1995) - têm proposto que a cultura está diretamente relacionada a "modos de vida", e isso implica a consideração permanente e simultânea dos vários aspectos aí presentes, numa relação que necessariamente envolve produtores, receptores e produtos culturais. ${ }^{16}$ Mais do que isso, acrescento: uma relação que supõe, por parte do estudioso, a tarefa de investigar e descrever o presente, problematizando o que, nas diferentes instâncias sociais (como a mídia e suas relações com a educação), é dado como verdade.

${ }^{15}$ Obviamente, Martín-Barbero está aí servindo-se de seu clássico conceito de mediação (sobre o qual nos abstemos de discorrer, tal a quantidade de estudos que o citam e tal a produtividade de seu emprego, já há mais de 20 anos, nos estudos de recepção).

${ }^{16}$ Ver, a propósito, a discussão sobre mídia e novas formas de investigação sobre o público e o privado, Thompson (2002). 
Nos textos "The work of representation" e "The spectacle of the 'other"' - em que Stuart Hall (1997) se dedica a expor densa e extensamente alguns conceitos como discurso, representação e diferença -, encontramos um bom exemplo da proposta aqui feita, de como a análise de imagens ou textos midiáticos pode vir profundamente articulada a uma discussão teórica sobre temas e problemas de nosso tempo, de modo que a investigação sobre os processos comunicacionais transite, no mínimo, por dois pólos principais, sempre relacionados entre si: o pólo da produção (da elaboração, da construção lingüística, sonora e imagética) e o pólo da recepção ${ }^{17}$ (ou seja, da operação sobre os materiais, que inclui, no caso desse autor e dos relatos publicados nessa obra em especial, um trabalho pedagógico muito particular, de ensino e aprendizagem sobre a cultura). Ambos estão estreitamente relacionados ao que eu chamaria propriamente de investimento teórico (relativo à escolha de produtos e temáticas muito específicos, intencionais, que permitam trazer à tona a discussão de conceitos de ordem filosófica, psicanalítica, sociológica, histórica, pedagógica, centrais para a própria compreensão da cultura contemporânea - por exemplo, questões sobre a filosofia da diferença, racismo, violência, relações de gênero, e assim por diante, como é

${ }^{17} \mathrm{Na}$ pesquisa "Subjetividade feminina e diferença no dispositivo pedagógico da mídia", que desenvolvo atualmente, realizo um estudo de recepção, aliado a uma investigação sobre produtos televisivos que tenham como figura proeminente a mulher. Nas sessões de recepção (feitas com alunas de um curso de pedagogia), interessou-me debater com as estudantes exatamente a temática das relações entre vida pública e vida privada, construção de novas identidades e subjetividades, invasão da intimidade no espaço "público" da mídia, produção e tratamento das diferenças, a partir de Homi Bhabha (1998) e, igualmente, do conceito de normalidade e anormalidade em Foucault, referências que, com os conceitos relativos à "televisibilidade" (Sarlo, 1997a) e aos "modos de endereçamento" (Ellsworth, 1997), conduziram as análises dos produtos televisivos e, igualmente, as sessões de "escuta" dos grupos de mulheres, bem como a análise desses mesmos textos (as falas das alunas). fartamente exemplificado por Hall no seu texto sobre "o espetáculo do outro", referido anteriormente). ${ }^{18}$

Imagino ter contribuído aqui para ampliar a discussão sobre nossas investigações a respeito das imagens da mídia na pesquisa educacional, tendo buscado articular aqueles dois pólos citados, tensionados por uma discussão que poderia ser chamada de temática/teórica. Com isso, assumo mais uma vez a urgência e a riqueza de pautar as análises da mídia a partir da idéia de que não só "vemos" tantas e tão diferentes imagens, mas somos igualmente "olhados" por elas. ${ }^{19}$ Olhar, como escreve Marilena Chaui, abriga necessariamente a crença na atividade da visão, e esta depende de nós, de nossa atividade, mas igualmente de uma certa passividade, daquilo que nasce "lá fora, no grande teatro do mundo" (Chaui, 1999, p. 34). Procurei argumentar em favor de um modo de investigar as relações entre emissor/receptor, produto/apropriação, a partir da idéia de prática cultural como prática política, ou de espaço público como teatralidade, agonismo, experiência de pluralidade (ver Arendt, 2000), para além do clássico binarismo de "conteúdo" e "forma". Pelo contrário, quis mostrar que há uma complementaridade entre esses dois aspectos; mais, que há uma inseparabilidade fundamental entre ambos.

A análise dos processos comunicacionais, à medida que dê conta da complexidade da produção/ emissão/veiculação, e igualmente da recepção/apropriação, e, principalmente, da colocação em pauta de temáticas contemporâneas - de modo especial, de conceitos teóricos claramente definidos -, pode ser oferecida como possível, plausível e produtiva, nas análises que estamos empreendendo no cruzamento dos campos da educação e da comunicação. Defendo aqui uma posição que espero ter explicitado suficientemente: nossas análises dos meios de co-

${ }^{18}$ Em meu livro Televisão \& educação: fruir e pensar a TV (Fischer, 2001c), chamo a atenção para algumas dessas questões que denomino "sintomas da cultura".

${ }^{19}$ Ver, a propósito, Didi-Huberman (1998). 
municação e informação, no espaço das pesquisas educacionais, estão a exigir, nestes tempos que vivemos, articulações mais densas e comprometidas com a própria complexidade dos processos comunicacionais. A meu ver, como procurei demonstrar neste artigo, uma possibilidade é a de investirmos na análise do discurso dos textos midiáticos sem perder de vista, de algum modo, aquilo que diz respeito aos modos e "exercícios do ver" ${ }^{20}$ dos diferentes públicos. No entanto, mais importante do que isso, a proposta é que tais investigações sobre produtos midiáticos e seus públicos sejam tecidas a partir de uma genuína preocupação com a história do presente, com atenção naquilo que hoje se faz urgente pensar aceitando que "o visível é atapetado pelo forro do invisível", e que "também o pensado é habitado pelo impensado" (Chaui 1999, p. 61). Nesse sentido, imagino que o esforço estará em mergulhar sem medo nossos estudos em teorias que dialogam com os "perigos" contemporâneos, como escreve Foucault (1995, p. 256), sem procurar propriamente alternativas, mas incessantemente trabalhar com problematizações, já que, ao fim e ao cabo, tudo é mesmo muito perigoso.

ROSA MARIA BUENO FISCHER é professora adjunta do Departamento de Estudos Especializados e do Programa de PósGraduação da Faculdade de Educação, da Universidade Federal do Rio Grande do Sul (UFRGS). Como pesquisadora, trabalha com a temática das relações entre mídia, cultura, discurso, modos de subjetivação e educação. Durante dez anos trabalhou na TV Educativa do Rio de Janeiro, como coordenadora de programas para crianças, adolescentes e professores. É autora dos livros $O$ mito na sala de jantar (Movimento, 1993, 2a ed.) e Televisão \& educação; fruir e pensar a TV (Autêntica, 2001). Publicou também vários artigos em revistas especializadas, além de ensaios e capítulos de livros, sobre os temas de suas pesquisas. Desde 1997 é editora da revista Educação \& Realidade, da Faculdade de Educação da UFRGS. Participou, de 1998 até 2000, do Comitê Científico da ANPEd.

${ }^{20}$ Como escrevem Jesús Martín-Barbero e Germán Rey (2001).

\section{Referências bibliográficas}

ARENDT, Hannah, (2000). A condição humana. Rio de Janeiro: Forense.

BHABHA, Homi, (1998). O local da cultura. Belo Horizonte: UFMG.

BERGER, John, (1999). Modos de ver. Rio de Janeiro: Rocco.

BORELLI, Sílvia Helena Simões, (1995). Gêneros ficcionais: materialidade, cotidiano, imaginário. In: SOUSA, Mauro Wilton de (org.). Sujeito, o lado oculto do receptor. São Paulo: Brasiliense.

CHAUI, Marilena, (1999). Janela da alma, espelho do mundo. In: NOVAES, Adauto (org.). O olhar. São Paulo: Cia. das Letras.

COSTA, Jurandir Freire, (2001). Subjetividade exterior. Disponível em: <http://www.jfreirecosta.hpg.ig.com.br/Ciencia_e_Educacao/ 9/Artigos/subjetividade.html>.

DIDI-HUBERMAN, Georges, (1998). O que vemos, o que nos olha. Rio de Janeiro: Ed. 34.

DELEUZE, Gilles, (1991). Foucault. São Paulo: Brasiliense.

DELEUZE, Gilles, GUATTARI, Félix, (2001). O que é a filosofia? Rio de Janeiro: Ed. 34.

ELLSWORTH, Elizabeth, (1997). Teaching positions: difference, pedagogy and the power of address. New York: Teachers College, Columbia University.

FISCHER, Rosa Maria Bueno, (1993). O mito na sala de jantar. Porto Alegre: Movimento.

(1996a). Adolescência em discurso: mídia e produção de subjetividade. Tese de doutorado - UFRGS/PPGEDU, Porto Alegre.

(1996b). A paixão de "trabalhar com” Foucault. In: COSTA, Marisa Vorraber (org.) Caminhos investigativos: novos olhares na pesquisa em educação. Porto Alegre: Mediação. p. 37-60.

(1997). O estatuto pedagógico da mídia: questões de análise. Educação \& Realidade. Porto Alegre, UFRGS/ FACED, v. 22, nº 2, jul./dez.

(1999). Foucault e o desejável conhecimento do sujeito. Educação \& Realidade. Porto Alegre, UFRGS/FACED,v. $24, n^{\circ} 1$, jan./jun., p. 39-59. 
, (2000). "Técnicas de si” na TV: a mídia se faz pedagógica. Educação UNISINOS, São Leopoldo (RS), v. 4, n 7, jul./dez.,p. 111-139.

, (2001a). Foucault e a análise do discurso em educação. Cadernos de Pesquisa, São Paulo, FCC/Autores Associados, n 114 , p. 197-223.

, (2001b). Mídia e educação da mulher: uma discussão teórica sobre modos de enunciar o feminino na TV. Revista Estudos Feministas, Florianópolis, UFSC, v. 9, n² 2, p. 586599.

, (2001c). Televisão \& educação: fruir e pensar a TV. Belo Horizonte: Autêntica.

FOUCAULT, Michel, (1986). A arqueologia do saber. Rio de Janeiro: Forense.

, (1991). Vigiar e punir. Petrópolis: Vozes.

, (1995). Sobre a genealogia da ética: uma revisão do trabalho. (Michel Foucault entrevistado por Hubert L. Dreyfus e Paul Rabinow). In: DREYFUSS, Hubert, RABINOW, Paul. Uma trajetória filosófica. Para além do estruturalismo e da hermenêutica. Rio de Janeiro: Forense.

GOMES, Paola Menna Barreto, (2000). Princesas: produção de subjetividade feminina no imaginário de consumo. Dissertação (Mestrado) - PPGEDU/UFRGS, Porto Alegre.

, (2002). Anatomia do dragão: imagens do mal na indústria do entretenimento. PPGEDU/UFRGS: Porto Alegre. (Proposta de tese de doutorado).

HALL, Stuart, (1997). Representation: cultural representations and signyfying pratices. Londres: Sage/Open University.

JACKS, Nilda, (2000). Histórias de família \& etnografia: procedimentos metodológicos para uma análise integrada. In: Mídias e recepção. São Leopoldo: UNISINOS.

MACHADO, Arlindo, (1988). A arte do vídeo. São Paulo: Brasiliense. MARCELLO, Fabiana de Amorim, (2002). Das configurações de um dispositivo: a maternidade como significante vazio PPGEDU/UFRGS, Porto Alegre. (Proposta de dissertação de mestrado).

MARTÍN-BARBERO, Jesús, (1995). América Latina e os anos recentes: o estudo da recepção em comunicação social. In: SOUSA, Mauro Wilton de (org.). Sujeito, o lado oculto do receptor. São Paulo: Brasiliense.

MARTÍN-BARBERO, Jesús; REY, Germán, (2001). Os exercícios do ver. Hegemonia audiovisual e ficção televisiva. São Paulo: SENAC.

MORIN, Edgar, (1999). Por uma reforma do pensamento. In: PENA-VEJA, Alfredo, NASCIMENTO, Elimar Pinheiro do (orgs.). O pensar complexo. Edgar Morin e a crise de modernidade. Rio de Janeiro: Garamond.

ROSE, Gillian, (2001). Visual methodologies. Londres: Sage.

SARLO, Beatriz, (1997a). Cenas da vida pós-moderna; intelectuais, arte e videocultura na Argentina. Rio de Janeiro: Editora UFRJ.

(1997b). Paisagens imaginárias. São Paulo: EDUSP.

SANTOS, Luís Henrique Sacchi dos, (2002). Biopolíticas de HIV/AIDS no Brasil: uma análise dos anúncios televisivos das campanhas oficiais de prevenção (1986-2000). Tese (Doutorado).

SOUSA, Mauro Wilton de, (1995). Recepção e comunicação: a busca do sujeito. In: SOUSA, Mauro Wilton de, (org.). Sujeito, o lado oculto do receptor. São Paulo: Brasiliense. p. 13-38.

THOMPSON, John B., (2002). A mídia e a modernidade: uma teoria social da mídia. Petrópolis: Vozes.

VEYNE, Paul, (1982). Como se escreve a história. Foucault revoluciona a história. Brasília: UnB.

VITELLI, Celso (2002). Estação adolescência: identidades na estética do consumo. Dissertação (Mestrado).

Recebido em maio de 2002 Aprovado em junho de 2002 
the concept of habitus, based on the singularity of those social and cultural conditionings experienced by modern societies.

Key-words: socialisation, habitus, configuration, modernity.

\section{Marisa Vorraber Costa}

Ensinando a dividir o mundo; as perversas lições de um programa de televisão

Ao analisar o programa diário da Rede Globo de Televisão - Bambuluá - dirigido a crianças e adolescentes, eu apresento esse artefato cultural como um dispositivo que integra o aparato pedagógico das sociedades governamentais, ensinando muitas coisas às pessoas, entre elas, um conjunto de verdades que compõe o currículo no qual se aprende a dividir o mundo. Meu argumento é que boa parte da modelagem identitária empreendida pelas sociedades neoliberais é levada a efeito pela mídia e por outros artefatos da indústria cultural. Autores/as que desenvolvem análises da cultura contemporânea como Shirley Steinberg, Douglas Kellner e Stuart Hall, com pesquisadores/as de um campo que vem sendo denominado estudos foucaultianos (Jorge Larrosa, Nikolas Rose, Alfredo VeigaNeto), ajudam-me a entender esses artefatos como linguagens que investem no entretenimento como uma forma de produzir significados convenientes a projetos políticos, sociais e culturais hegemônicos, colocando em funcionamento técnicas de governo que forjam consciências e moldam comportamentos. Eles são parte da política cultural que dispõe pessoas e grupos hierarquicamente nas sociedades em que vivem. Palavras-chave: mídia e educação, educação e televisão, pedagogias culturais, estudos culturais, currículo.

Teaching how to divide the world; the perverse curriculum of a television programme
In analysing a Brazilian daily television programme for children and young people - Bambuluá - I present this cultural artefact as a device used for integrating the pedagogical apparatus of governmental societies, teaching people many things, including a set of truths which make up the curriculum through which we learn to divide the world. I argue that media pedagogies and other artefacts of the cultural industry carry out much of the identity shaping that is undertaken by contemporary neoliberal societies. Authors like Shirley Steinberg, Douglas Kellner and Stuart Hall, along with researchers from a field called Foucaultian studies (Jorge Larrosa, Nikolas Rose, Alfredo VeigaNeto), have helped me to understand these artefacts as languages which invest in entertainment as a way of producing convenient meanings for political, social and cultural hegemonic projects, putting into operation governmental techniques which conflate consciousness and shape behaviour. They are part of a cultural policy that deploys people and groups hierarchically in the societies in which they live.

Key-words: media and education, education and televison, cultural pedagogies, cultural studies, curriculum.

\section{Rosa Maria Bueno Fischer}

Problematizações sobre o exercício de ver: mídia e pesquisa em educação

Apresento e discuto uma proposta metodológica para investigações que, no campo educacional, tratam da análise de produtos da mídia, especialmente da televisão. Apoiada em autores como Foucault e Deleuze, Beatriz Sarlo e Martín-Barbero, argumento em favor de um trabalho de pesquisa que busque descrever, a partir de um estudo da linguagem audiovisual, os discursos que, circulando como verdade em nosso tempo, produzem, para indivíduos e diferentes grupos sociais, determinados modos de subjetivação. A análise dos discursos da mídia é entendida como uma ferramenta para descrever práticas discursivas e não-discursivas, o visível e o enunciável dos modos de ver contemporâneos.

Palavras-chave: mídia, recepção, análise do discurso, pesquisa em educação, subjetivação.

\section{Problematising ways of seeing:} media and educational research This article presents and discusses a methodological proposal for investigating media, especially television products, in the educational field. With theoretical support from authors like Foucault, Deleuze, Beatriz Sarlo and Martín-Barbero, I argue for investigations into audio-visual language that seek to describe discourses circulating as hegemonic truths, in order to produce determined ways of subjectivation. Analysis of discourse, related to media products, works as a "tool" for describing practices of discourse and nondiscourse about ways of seeing in contemporary life.

Key-words: media, reception, analysis of discourse, educational research, subjectivation.

\section{Ana Lúcia Silva Ratto}

\section{Cenários criminosos e pecaminosos} nos livros de ocorrência de uma escola pública

$\mathrm{O}$ artigo identifica relações entre a temática da confissão e a narrativa existente nos livros de ocorrência recentes de uma escola pública de Curitiba, baseando-se em referenciais analíticos pósestruturalistas. Esses livros relatam casos de alunos considerados pela escola como problemáticos e indisciplinados, contendo um total de 517 ocorrências nos anos de 1998 e 1999. Trata-se de 